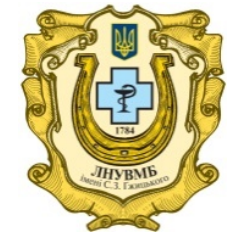

Ukrainian Journal of

Veterinary and Agricultural Sciences

http://ujvas.com.ua

Stepan Gzhytskyi National University of Veterinary Medicine and Biotechnologies Lviv

original article $\mid$ UDC 636.92.003.13: 636.085.55:547.1'147 | doi: 10.32718/ujvas1-2.01

Volume 1

Number 2

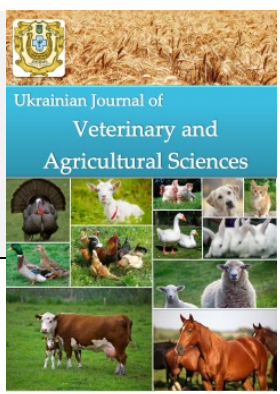

\title{
Productivity of growing rabbits for use of forrage with different zinc content
}

\author{
Yu.V. Pozniakovskyi, M.I. Holubiev, T.A. Holubieva \\ National University of Life and Environmental Sciences of Ukraine, \\ Heroiv Oborony str., 15, Kyiv, 03041, Ukraine
}

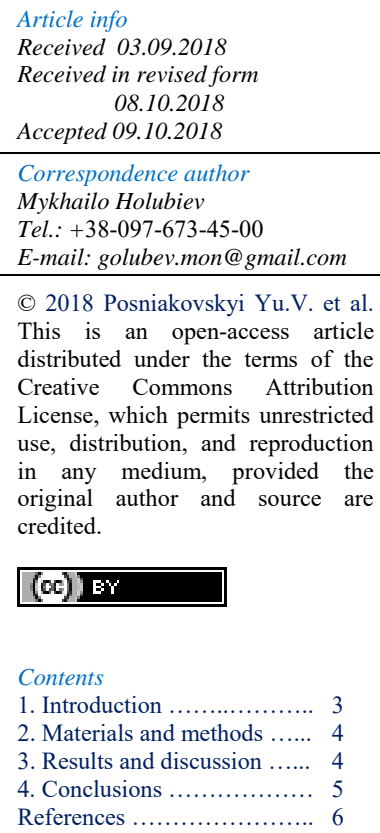

\begin{abstract}
The results of studies on the optimal level of zinc, which are additionally introduced into feed for rabbits grown for meat, are presented. Experimental researches were conducted in the conditions of the problematic research laboratory of feed additives of the National University of Life and Environmental Sciences of Ukraine. A scientific and economic experiment was carried out on growing rabbits of HYLA hybrids of the French company EUROLAP. The study was conducted by group method. In the 42-day age, 60 rabbits were selected, out of which, according to the analogues principle, three groups were formed - one control and two experimental, with 20 rabbits (10 females and 10 males) in each. The research lasted for 42 days. It was used full-grain granulated feed for feeding the experimental growing rabbits, which according to the chemical composition differed in content of zinc in them. Rabbits of the control group received feed containing zinc $50 \mathrm{mg} / \mathrm{kg}$, the second $-100 \mathrm{mg} / \mathrm{kg}$, the third $-150 \mathrm{mg} / \mathrm{kg}$. It was established that feeding of rabbits in the $43-$ 84-day-old age with feed containing zinc $100 \mathrm{mg} / \mathrm{kg}$ contributes to an increase in body weight by $2.9 \%$, and an increase in average daily growth during the growing season, respectively, by $4.7 \%$. Feed costs per $1 \mathrm{~kg}$ growth in growing rabbits consuming feed containing Zinc were 1.0\% lower than the control group's young. Rabbits which were fed with feed containing zinc $150 \mathrm{mg} / \mathrm{kg}$ were inferior to body weight and average daily increments, respective-ly, by $1.4 \%$ and $2.7 \%$ of animals fed with a feed with a zinc level of $50 \mathrm{mg} / \mathrm{kg}$.
\end{abstract}

Key words: rabbit, body weight, feed, zinc, feed costs.

\section{Citation:}

Pozniakovskyi, Yu.V., Holubiev, M.I., \& Holubieva, T.A. (2018). Productivity of growing rabbits for use of forrage with different zinc content. Ukrainian Journal of Veterinary and Agricultural Sciences, 1(2), 3-6.

\section{Introduction}

It is generally known that animals require a small amount of microelements in their diet, but these microelements play an important role in virtually all physiological and biochemical processes, from bone formation to promoting the synthesis of proteins and lipids.

In the diet of animals, microelements come from forage, in the form of special feed additives (premix) or with water. At the intensive production of livestock products, their addition is mandatory, since this is the only way to provide animals with sufficient amount of microelements, which are necessary to ensure the functional state of the organism and sustainable production.

One such microelement is zinc. It is a necessary mineral element in the natural environment, since it plays an important role in many biological processes. As an essential microelement, zinc is required for the normal growth and development of all higher plants and animals. In addition, it plays a key role in the physiological growth and participates in the immune processes of the body (Frassinetti et al., 2006).

Zinc also plays an antioxidant role in certain biochemical systems. It protects $\mathrm{SH}$-groups from oxidation and inhibits the formation of reactive oxysins by means of transition of metals (Bray and Bettgery, 1990). The results indicate that zinc may have a therapeutic potential in the treatment of oxidative damage to the liver along with increased absorption of nicotinic acid (Tupe et al., 2010). Data suggest that zinc level depression affects membrane signaling systems and intracellular secondary messengers that coordinate cell proliferation in response to IGF-I (MacDonald, 2000). In addition to its diverse role in many physiological systems, zinc is an important regulator of apoptosis (Truong-Tran et al., 2001).

Zinc and other mineral elements in the process of digestion affect the suction of each other. The excessive consumption of such elements as Calcium, Phosphorus, Copper and Iron reduces the absorption of zinc, and excessive consumption of zinc also reduces the absorption 
of some mineral elements (Iron, Copper, Calcium, Phosphorus and manganese) (Insel et al., 2007).

Therefore (Mateos and Blas, 1998) recommend using rations for rabbits containing Zinc from 30 to $60 \mathrm{mg} / \mathrm{kg}$ of dry matter. INRA (Blum, 1989) recommends a zinc level of $50 \mathrm{mg} / \mathrm{kg}$ on fattening and $70 \mathrm{mg} / \mathrm{kg}$ feed for reproductive animals. Taking into account that zinc is a heavy metal, its maximum level allowed in the European Union for animals is $250 \mathrm{mg} / \mathrm{kg}$ (European Commission, 2003).

Chrastinová L'. etc. (Chrastinová et al., 2015) note that in modern literature, rarely found research on the establishment of the need for zinc for rabbits, and the level of its use varies from 25 to $60 \mathrm{mg} / \mathrm{kg}$. Commercial feeds also contain a wider range of zinc (40-140 $\mathrm{mg} / \mathrm{kg})$.

While establishing the need for Zinc Hossain S., Bertechini A.G. (Hossain and Bertechini, 1993) observed an increase in body weight and feed in rabbits, which received an additional $90 \mathrm{mg} / \mathrm{kg}$ of zinc in the diet. Similar studies show that growing rabbits responded positively to $100 \mathrm{mg} /$ $\mathrm{kg}$ of supplemental zinc content by increasing body weight (Nessrin et al., 2012).

Taking into account certain differences in earlier established norms, the purpose of our study was to research the effects of feed with different levels of zinc on the productivity of growing rabbits.

\section{Materials and methods}

A comparative analysis to determine the optimal level of zinc in fodder for rabbits was carried out through the formulation of scientific and economic experience. Experimental studies were conducted at the Department of Animal Feeding and Feed Technology n.a. P.D. Pshenichny National University of Environmental and Life Sciences of Ukraine. In the 42-day age, 60 rabbits of the HYLA hybrid breed were selected from the French company EUROLAP, of which, according to the principle of analogues, three groups were formed - one control and two experimental, with 20 heads (10 females and 10 males) in each. The research lasted for 42 days.

A full-grain granulated feeds were used for feeding the experimental livestock of growing rabbits, which differed in their chemical composition of zinc according to the experimental scheme (Table 1).

Fodder and water of rabbits consumed loosely. Every week we conducted individual weighings of the experimental stock, calculation of increments and feed costs. The body mass was determined on the basis of the weight of the VDD-FD (F998-6ED) with an accuracy of $1 \mathrm{~g}$.

Table 1

Scheme of scientific and economic experiment

\begin{tabular}{lc}
\hline Group & Zinc content in forage, $\mathrm{mg} / \mathrm{kg}$ \\
\hline 1 control & 50 \\
2 research & 100 \\
3 research & 150 \\
\hline
\end{tabular}

The results of the research were subjected to the usual statistical data processing procedures using the MS Excel software with the use of embedded statistical functions (AVERAGE, STDEVP, SQRT, TTEST). While calculating the statistical significance, it was taken into account that the indicator " $\mathrm{P}$ " is characterized by the follow-ing: * $\mathrm{P}<0.05$ $* * \quad \mathrm{P}<0.01-$ "Statistically significant (sig-nificant) differences" are revealed.

\section{Results and discussion}

The ration for rabbits consisted of a full-grain granulated feed containing an insufficient amount of zinc, but was responsible for the content of energy and other nutrients to the standards specified in the relevant recommendations. The composition of forage and its content in energy and nutrients of feed are presented in Table 2 .

Table 2

Content of forage, $\%$

\begin{tabular}{lc}
\hline \multicolumn{1}{c}{ Component } & Content \\
\hline Wheat bran & 49.5 \\
Sunflower Shrot & 25.0 \\
Sunflower husk & 15.0 \\
Alfalfa herb flour & 8.0 \\
Bone Concentrate & 0.5 \\
Premix & 2.0 \\
\hline
\end{tabular}

Content of energy and main elements of nutrition are shown in the table 3 .

On the basis of the conducted researches it was established that feeding rabbits with mixed fodders with different content of zinc influenced their weight growth (Table 4).

Table 3

Content in $100 \mathrm{~g}$ of mixed fodders of energy and main nutritional elements for growing rabbits, $\%$

\begin{tabular}{lclc}
\hline \multicolumn{1}{c}{ Indicator } & Content & & \multicolumn{1}{c}{ Indicator } \\
\hline Exchange energy, MJ & 0.92 & Sodium & 0.23 \\
Crude protein & 17.65 & Zinc, mg & S0.0* \\
Crude fiber & 17.55 & Mangan, mg & 32.0 \\
Crude fat & 3.29 & Selenium, mg & 0.1 \\
Lysine & 0.85 & Cobalt, mg & 0.5 \\
Methionine & 0.29 & Iodine, mg & 0.5 \\
Tryptophan & 0.22 & Vitamin A, th. IU \\
Calcium & 1.19 & Vitamin D, th. IU \\
Phosphorus & 0.74 & Vitamin E, mg & 1.0 \\
\hline
\end{tabular}

Note: * the content of zinc in feed for experimental groups varied according to the experimental scheme 
Table 4

Body weight of growing rabbits, gr.

\begin{tabular}{cccc}
\hline \multirow{2}{*}{ Age, days } & \multicolumn{3}{c}{ Group } \\
\cline { 2 - 4 } & 1 & 2 & 3 \\
\hline 42 & $1245.2 \pm 10.66$ & $1243.3 \pm 9.98$ & $1247.1 \pm 9.14$ \\
49 & $1620.2 \pm 12.42$ & $1638.7 \pm 12.31$ & $1619.5 \pm 12.44$ \\
56 & $1934.7 \pm 14.08$ & $1967.2 \pm 13.04$ & $1928.9 \pm 12.07$ \\
63 & $2273.1 \pm 14.86$ & $2316.1 \pm 15.09$ & $2256.7 \pm 13.93$ \\
70 & $2510.6 \pm 15.62$ & $2571.3 \pm 15.72^{*}$ & $2496.4 \pm 15.62$ \\
77 & $2744.9 \pm 17.18$ & $2816.5 \pm 16.07^{* *}$ & $2729.9 \pm 16.23$ \\
84 & $2940.8 \pm 18.74$ & $3024.8 \pm 15.42^{* *}$ & $2900.1 \pm 16.73$ \\
\hline
\end{tabular}

Note: ${ }^{*} \mathrm{P}<0.05 ;{ }^{* *} \mathrm{P}<0.01$ in relation to control group

Due to the careful selection of animals in the formation of groups, at the beginning of the experiment, the difference in weight of the body of rabbits did not exceed $0.2 \%$.

There was no probable difference in body weight between animals in control and experimental groups up to 70 days of age. However, rabbits consuming $100 \mathrm{mg} / \mathrm{kg}$ of zinc compounded by this indicator were prevailed over analogues of the control group, and the young group of the third group (150 mg/kg of zinc), on the contrary, was inferior to control.

At 70 days of age, rabbits in the second group had $2.4 \%$ $(\mathrm{P}<0,05)$ greater body weight than those of the control group. The third group's growing rabbits were inferior to this indicator by $0.6 \%$. A similar trend was observed at 77 days of age - rabbits of the third group had a smaller $0.5 \%$, and animals of the second group - by $2.6 \%(\mathrm{P}<0.01)$ greater body weight than control.

At the end of the experiment, the largest body weight had rabbits of the second group - $3024.8 \mathrm{~g}$, which is $2.9 \%$ $(\mathrm{P}<0.01)$ more than the corresponding indicator of animals in the control group.

A similar situation was observed with respect to changes in average daily increments (Table 5).

Table 5

Average daily weight gains of growing rabbits, $g$.

\begin{tabular}{cccc}
\hline \multirow{2}{*}{ Age period, days } & \multicolumn{2}{c}{ Group } \\
\cline { 2 - 4 } & 1 & 2 & 3 \\
\hline $43-49$ & $53.6 \pm 0.95$ & $56.5 \pm 1.00^{*}$ & $53.4 \pm 0.86$ \\
$50-56$ & $44.6 \pm 0.85$ & $46.6 \pm 1.29$ & $44.2 \pm 1.05$ \\
$57-63$ & $48.3 \pm 1.32$ & $49.8 \pm 1.33$ & $46.8 \pm 1.61$ \\
$64-70$ & $34.6 \pm 1.65$ & $36.5 \pm 1.48$ & $34.2 \pm 1.55$ \\
$71-77$ & $33.5 \pm 1.33$ & $35.0 \pm 1.12$ & $33.4 \pm 1.17$ \\
$78-84$ & $28.0 \pm 1.16$ & $29.8 \pm 0.75$ & $24.3 \pm 0.97^{*}$ \\
During the whole research period & $40.5 \pm 0.33$ & $42.4 \pm 0.24^{* * *}$ & $39.4 \pm 0.37$ \\
\hline
\end{tabular}

Note: ${ }^{*} \mathrm{P}<0.05 ;{ }^{* * *} \mathrm{P}<0.001$ in relation to control group

In all ages, the greatest increments were observed in rabbits of the second group, they fluctuated within $29.8-56.5 \mathrm{~g}$, while the smallest - in animals of the third group - from 24.3 to $53.4 \mathrm{~g}$.

The average daily gain for the whole period of the experiment was the highest in the rabbits of the second group, which is $4.7 \%(\mathrm{P}<0.001)$ more than the control. Animals of the third group had a smaller increase by $2.7 \%$ compared to the control rabbit group.

An important characteristic of animal productivity is the feed costs per unit of growth, the results of which are presented in Table 6 .

\section{Table 6}

Forage costs per $1 \mathrm{~kg}$ of weight gain, $\mathrm{kg}$

\begin{tabular}{cccc}
\hline Age period, days & \multicolumn{3}{c}{ Group } \\
\cline { 2 - 4 } & 1 & 2 & 3 \\
\hline $43-49$ & 2.165 & 2.160 & 3.054 \\
$50-56$ & 3.091 & 3.048 & 3.374 \\
$57-63$ & 3.310 & 3.391 & 4.908 \\
$64-70$ & 4.936 & 4.827 & 5.306 \\
$71-77$ & 5.347 & 5.339 & 7.526 \\
$78-84$ & 6.647 & 6.485 & 4.384 \\
\hline
\end{tabular}

Forage costs per unit of growth in different growing periods fluctuated in groups from 2.135 to $6.647 \mathrm{~kg}$.

The estimates of forage costs during the growing period of 42-84 days indicate that the rabbits that consumed feed containing zinc $100 \mathrm{mg} / \mathrm{kg}$ of body weight gain consumed it by $1.0 \%$ less than control. The young, who consumed feed containing zinc $150 \mathrm{mg} / \mathrm{kg}$, vice versa, consumed feed $3.2 \%$ more than the growing rabbits of the control group.

\section{Conclusions}

It was experimentally proved on the basis of the research 
that the expediency of using full-grain granulated forage with the level of zinc $100 \mathrm{mg} / \mathrm{kg}$.

Feeding rabbits in the 43-84-day-old age with forage containing zinc $100 \mathrm{mg} / \mathrm{kg}$ contributes to an increase in body weight by $2.9 \%$, and an increase in average daily growth during the growing season, respectively, by $4.7 \%$.

The forage costs per $1 \mathrm{~kg}$ growth in growing rabbits consuming feed containing Zinc were 1.0\% lower than the growing rabbits of the control group.

Rabbits were fed with forage containing zinc $150 \mathrm{mg} /$ $\mathrm{kg}$ were inferior to body weight and average daily increments, respectively, by $1.4 \%$ and $2.7 \%$ of animals fed a forage with a zinc level of $50 \mathrm{mg} / \mathrm{kg}$.

\section{References}

Frassinetti, S., Bronzetti, G., Caltavuturo, L., Cini, M., \& Croce, C.D. (2006). The role of zinc in life: a review. J Environ Pathol Toxicol Oncol, 25(3), 597-610. doi: 10.1615/JEnviron PatholToxicolOncol.v25.i3.4.

Bray, T.M., \& Bettger, W.J. (1990). The physiological role of zinc as an antioxidant. Free Radic Biol Med, 8(3), 281-291. doi: 10.1016/0891-5849(90)90076-U.

Tupe, R.S., Tupe, S.G., Tarwadi, K.V., \& Agte, V.V. (2010). Effect of different dietary zinc levels on hepatic antioxidant and micronutrients indices under oxidative stress conditions. Metabolism, 59(11), 1603-1611. doi: 10.1016/j.metabol.2010.02.020.
MacDonald, R.S. (2000). The Role of Zinc in Growth and Cell Proliferation. The Journal of Nutrition, 130(5), 1500S-1508S. doi: $10.1093 / \mathrm{jn} / 130.5 .1500 \mathrm{~S}$

Truong-Tran, A.Q., Carter, J., Ruffin, R.E., \& Zalewski, P.D. (2001). The role of zinc in caspase activation and apoptotic cell death. BioMetals, 14(3-4), 315-333. doi: 10.1023/A:1012993017026.

Insel, P.M., Turner, R.E., \& Ross, D. (2007). Nutrition. 3th ed. Jones and Bartlett Publishers.

Mateos, G.G., \& Blas, C. (2009). Minerals, vitamins and additives. In: Blas, C., Wiseman, J. The nutrition of the rabbit. London: CABI Publ., 145-175. doi: 10.1079/9781845936693.0000.

Blum, J.C. (1989). Elevage des Monogastriques. L'alimentation des animaux monogastriques: porc, lapin, volailles. Paris, FRA: INRA.

EC (European Commission). Opinion of the Scientific Committee for Animal Nutrition on the use of zinc in feedingstuffs. Available from online. http://ec.europa.eu/food/fs/sc/scan/ out120 en.pdf.

Chrastinová, L., Čobanová, K., Chrenková, M., Poláčiková, M., Formelová, Z., Lauková, A., Ondruška, L'. Pogány Simonová, M., Strompfová, V., Bučko, O., Mlyneková, Z., Mlynár, R., \& Grešáková, L. (2015). High dietary levels of zinc for young rabbits. Slovak J. Anim. Sci., 48(2), 57-63. http://www.cvzv.sk/slju/15 2/2 chrastinova.pdf.

Hossain, S., \& Bertechini, A.G. (1993). Requirement of zinc for growing rabbits. Arq. Bras. Med. Vet. Zootec., 45, 323-329.

Nessrin, S., Abdel-Khalek, A.M., \& Gad, S.M. (2012). Effect of supplemental zinc, magnesium or iron on performance and some physiological traits of growing rabbits. Asian J. Poul. Sci., 6, 23-30. doi:10.3923/ajpsaj.2012.23.30. 